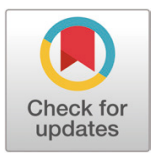

Received: Mar 23, 2020

Revised: May 10, 2020

Accepted: May 14, 2020 \#These authors contributed equally to
this work.

*Corresponding author Koo Bok Chin

Department of Animal Science, Chonnam National University,

Gwangju 61186, Korea

Tel: +82-62-530-2121

E-mail: kbchin@chonnam.ac.kr

Copyright $@ 2020$ Korean Society of Animal Sciences and Technology.

This is an Open Access article distributed under the terms of the Creative Commons Attribution Non-Commercial License (http:// creativecommons.org/licenses/by$\mathrm{nc} / 4.0 /$ ) which permits unrestricted non-commercial use, distribution, and reproduction in any medium, provided the original work is properly cited.

ORCID

Ji Seon Choi

https://orcid.org/0000-0002-4773-0743

Koo Bok Chin

https://orcid.org/0000-0002-8062-6331

Competing interests

The authors declare no conflict of interest.

Funding sources

This work was supported by

Technology development program (\# PJ013809022018) for Rural

Development Administration, Korea.

\section{Evaluation of physicochemical and textural properties of chicken breast sausages containing various combinations of salt and sodium tripolyphosphate}

\author{
Ji Seon Choi ${ }^{\#}$ and Koo Bok Chin ${ }^{\# *}$ \\ Department of Animal Science, Chonnam National University, Gwangju 61186, Korea
}

\begin{abstract}
This study was to investigate the effect of salt alone or in combination with phosphate on physicochemical and textural properties, and chemical interactions of low-fat model sausages. $\mathrm{pH}$, color, expressible moisture (EM), cooking loss (CL), proximate analysis, textural profile analysis and low-vacuum scanning electron microscopy were performed. As salt content increased, color tended to decrease, as did EM and CL parameters, indicating that the ability to retain moisture was improved with increased salt levels $(p<0.05)$. In addition, textural hardness, gumminess and chewiness all increased with increasing salt $(p<0.05)$. Sausages with $0.3 \%$ salt showed the lowest cohesiveness compared to those with salt levels higher than $0.3 \%(p<0.05)$. Addition of sodium tripolyphosphate (STPP) increased $\mathrm{pH}$ of sausages. Increasing salt and STPP did not affect lightness $(p>0.05)$, but did increase redness and yellowness $(p<0.05)$. The moisture content was higher when the salt and STPP contents were increased $(p<0.05)$, but no differences in the fat and protein contents $(\%)$ were observed ( $p$ $>0.05$ ). EM and CL tended to decrease with increasing salt and STPP. In textural properties, the combination of $1.8 \%$ salt and $0.3 \%$ STPP was the best among other treatment $(p<0.05)$. Surface microstructure showed a flat and dense structure with increasing salt and STPP. Since the addition of salt and phosphate improved the functionality, textural and physicochemical properties of meat products in this study, meat products will need to be developed in line with consumer's preference.
\end{abstract}

Keywords: Chicken breast, Sausages, Salt, Sodium tripolyphosphate

\section{INTRODUCTION}

Salt and phosphate are key additives that play an important role in the quality of meat products. However, excessive additives intake adversely affects human health. Because of these potential risks, consumers want to have a food reduced ingredients. Thus, consumers want foods that have reduced or eliminated additives, so-called "clean label" foods, because additives are considered unsafe and po- 
Acknowledgements

Not applicable.

Availability of data and material Upon reasonable request, the datasets of this study can be available from the corresponding author.

Authors' contributions Conceptualization: Choi JS, Chin KB. Data curation: Choi JS, Chin KB. Formal analysis: Choi JS, Chin KB. Investigation: Choi JS, Chin KB.

Writing - original draft: Choi JS.

Writing - review \& editing: Chin KB.

Ethics approval and consent to participate This article does not require IRB/IACUC approval because there are no human and animal participants. tentially harmful by consumers [1]. Due to greater scientific literacy and popular sources of media information, consumers are well aware of the relationship between sodium and diseases, in particular hypertension. This leads to increasing demand for low salt products in many countries. Salt gives meat products salty flavor which is due to $\mathrm{Na}^{+}$with $\mathrm{Cl}^{-}$modifying the perception [2,3]. It also solubilizes the myofibrillar protein in meat products and improves meat product gelation, hydration, water-binding capacity, cooking loss (CL) and texture [3]. The addition of phosphate leads to increased electronegativity and the electrostatic repulsion of protein interaction. Therefore, protein dispersed in water has greater solubility, and emulsifying and foaming ability when phosphate is present [4]. It can also increase $\mathrm{pH}$ of meat products, dissociate actin and myosin and bind to the meat protein [5,6]. Among the phosphate compound, sodium tripolyphosphate (STPP) has been widely using in the meat industry because of its safety, low cost and simple operation $[4,7]$. The salt effect is enhanced by phosphate, because $\mathrm{NaCl}$ and phosphate act synergistically in the depolymerisation of thick filaments [6]. In addition, many studies have reported that the combination of salt and phosphate contributes to quality improvements (i.e., binding property, water retention, emulsion stability, sensory property) of meat products $[8,9]$. To develop a clean label meat product, we evaluated the optimal combination to reduce additives without significantly impairing the quality according to the amount of salt and phosphate added. Therefore, this study was performed to evaluate quality of chicken breast sausage containing various combinations of salt and STPP.

\section{MATERIALS AND METHODS}

\section{Materials}

Raw chicken breasts were purchased from the local market and stored at $-70^{\circ} \mathrm{C}$ in freezer until used. Frozen chicken breasts were thawed overnight at $4{ }^{\circ} \mathrm{C}$. After thawing, the meat was ground by meat chopper (M-12S, Hankook Fujee Machinery, Gyeonggi, Korea) and used for the manufacture of chicken model sausages.

\section{Experiment 1: Quality of chicken breast sausage with various levels of salt Manufacture of chicken breast sausages}

Table 1 shows the formulation of model chicken sausages with varying salt levels (T1-T5). Model sausages were processed with $0.3 \%, 0.8 \%, 1.3 \%, 1.8 \%$, and $2.3 \%$ salt, but actual salt content was $0.5 \%$, $1.0 \%, 1.5 \%, 2.0 \%$ and $2.5 \%$, since cure blend included the salt ( $\sim .2 \%)$. Ground chicken breast was mixed with ice water and non-meat ingredients (salt, STPP, sodium erythorbate and cure blend)

Table 1. Formulation of chicken sausages with various levels of salt

\begin{tabular}{|c|c|c|c|c|c|}
\hline \multirow{2}{*}{ Ingredients } & \multicolumn{5}{|c|}{ Treatments (\%) } \\
\hline & TRT1 & TRT2 & TRT3 & TRT4 & TRT5 \\
\hline \multicolumn{6}{|l|}{ Raw meat } \\
\hline Chicken breast & 80.0 & 80.0 & 80.0 & 80.0 & 80.0 \\
\hline Ice water & 19.0 & 19.0 & 19.0 & 19.0 & 19.0 \\
\hline \multicolumn{6}{|l|}{ Non-meat ingredients } \\
\hline Salt & 0.30 & 0.80 & 1.30 & 1.80 & 2.30 \\
\hline STPP & 0.40 & 0.40 & 0.40 & 0.40 & 0.40 \\
\hline Sodium erythorbate & 0.05 & 0.05 & 0.05 & 0.05 & 0.05 \\
\hline Cure blend & 0.25 & 0.25 & 0.25 & 0.25 & 0.25 \\
\hline Total & 100.0 & 100.5 & 101.0 & 101.5 & 102.0 \\
\hline
\end{tabular}

TRT1, Treatment 1 (0.3\% salt); TRT2, Treatment 2 ( $0.8 \%$ salt); TRT3, Treatment 3 (1.3\% salt); TRT4, Treatment 4 (1.8\% salt); TRT5, Treatment 5 (2.3\% salt). 
using a food mixer (HMC-401, Hanil Electric, Seoul, Korea) for $3.5 \mathrm{~min}$. Approximately, $40 \mathrm{~g}$ of sausage batter was placed into $50 \mathrm{~mL}$ conical tubes (SPL Life Science, Gyeonggi, Korea) and centrifuged at 1,660×g for $2 \mathrm{~min}$ using a centrifuge (VS-5500, Vision Science, Seoul, Korea) then sausages were cooked at $75^{\circ} \mathrm{C}$ for $30 \mathrm{~min}$. When cooking was done, the cooked sausages were placed in an ice box for $30 \mathrm{~min}$, and then stored at $4^{\circ} \mathrm{C}$ until utilized.

\section{pH and color measurement}

$\mathrm{pH}$ of sausages was measured on five times using $\mathrm{pH}$-meter (MP-120, Mettler-Toledo, Greifeense, Switzerland). The inner surface of sausages was used to measure their color values. Lightness (CIE $\left.L^{*}\right)$, redness $\left(\mathrm{CIE} \mathrm{a}^{*}\right)$ and yellowness $\left(\mathrm{CIE} \mathrm{b}^{*}\right)$ were evaluated on six times using the color reader (CR-10, Minolta, Tokyo, Japan).

\section{Expressible moisture (EM, \%) and cooking loss (g)}

Water-holding capacity was performed by modifications base on the method described in Jauregui [10]. Sausage samples cubes $(1.5 \mathrm{~g})$ were prepared, and then wrapped with three pieces of Whatman \#3 filter paper. After samples and filter paper pieces were weighed, they were centrifuged at 1,660×g for $15 \mathrm{~min}$, and then weights were measured again. The expressible moisture (EM) was calculated by the equation. EM (\%) = (filter paper weight after centrifuge - original filter paper weight) / original sample weight $\times 100$. The CL was calculated by weight difference after cooking. CL (g) = sample weight $(40 \mathrm{~g})$ before cooking - sample weight $(\mathrm{g})$ after cooking.

\section{Textural profile analysis (TPA)}

Ten pillar shaped samples were prepared using a puncturing tool. Sample's height was $13 \mathrm{~mm}$ and diameter was $12.5 \mathrm{~mm}$. An Instron Universal Testing Machine (Model 3344 testing device, Norwood, MA, USA) was utilized to analyze the textural quality of chicken breast sausage. The sample height was reduced to $75 \%$ of the original height after samples were compressed two times sequentially. A compression probe was utilized with a $500 \mathrm{~N}$ load cell and the crosshead speed was 300 $\mathrm{mm} / \mathrm{min}$. Hardness (gf), springiness ( $\mathrm{mm}$ ), gumminess, chewiness, and cohesiveness were measured following the method of Bourne [11].

\section{Experiment 2: Quality of chicken breast sausage with various levels of salt and sodium tripolyphosphate}

\section{Manufacture of chicken breast sausages}

Table 2 indicate the formulation of model chicken breast sausages with various combination of salt and STPP. Model sausages were made with $0 \%, 0.8 \%$, or $1.8 \%$ salt and with or without $0.3 \%$ STPP and mixing was performed using a food mixer (HMC-401, Hanil Elecric, Seoul, Korea) for 3.5 min. The following measurements were the same as in Experiment 1.

\section{$\mathrm{pH}$, color and proximate analysis}

$\mathrm{pH}$ and color measurement were performed as in Experiment 1. Proximate analysis was measured by AOAC method [12]. Moisture was measured by dry-oven method, crude fat content by Soxhlet extraction method, and crude protein by Kjeldahl method.

\section{EM (\%), CL (g) and TPA}

Performed as in Experiment 1 [10,11]. 
Table 2. Formulation of chicken sausages with various levels of salt and sodium tripolyphosphate (STPP)

\begin{tabular}{|c|c|c|c|c|c|c|}
\hline \multirow{2}{*}{ Ingredients } & \multicolumn{6}{|c|}{ Treatments (\%) } \\
\hline & TRT6 & TRT7 & TRT8 & TRT9 & TRT10 & TRT11 \\
\hline \multicolumn{7}{|l|}{ Raw meat } \\
\hline Ice water & 19.7 & 19.7 & 19.7 & 19.7 & 19.7 & 19.7 \\
\hline \multicolumn{7}{|l|}{ Non meat ingredients } \\
\hline Sodium erythorbate & 0.05 & 0.05 & 0.05 & 0.05 & 0.05 & 0.05 \\
\hline Cure blend & 0.25 & 0.25 & 0.25 & 0.25 & 0.25 & 0.25 \\
\hline Total & 100.0 & 100.3 & 100.8 & 101.1 & 101.8 & 102.1 \\
\hline
\end{tabular}

TRT6, Treatment 6 ( $0 \%$ salt, 0\% STPP); TRT7, Treatment 7 ( $0 \%$ salt, 0.3\% STPP); TRT8, Treatment 8 ( $0.8 \%$ salt, 0\% STPP); TRT9, Treatment 9 (0.8\% salt, $0.3 \%$ STPP); TRT10, Treatment 10 (1.8\% salt, $0 \%$ STPP); TRT11, Treatment 11 (1.8\% salt, $0.3 \%$ STPP).

\section{Low-vacuum scanning electron microscopy (LV-SEM)}

Scanning electron microscopy was performed to determine the three-dimensional structures of each sausage. Cube shaped samples $\left(3 \times 3 \times 3 \mathrm{~mm}^{3}\right)$ were prepared. Samples were fixed using $2.5 \%$ glutaraldehyde solution which was dissolved in $0.1 \mathrm{M}$ sodium phosphate buffer $(\mathrm{pH} 7)$ overnight at $4^{\circ} \mathrm{C}$. The samples were washed one time using $0.1 \mathrm{M}$ sodium phosphate buffer $(\mathrm{pH} 7)$ and immersed in phosphate buffer containing osmium tetroxide for $5 \mathrm{hrs}$. Thereafter, the samples were washed three times for $10 \mathrm{~min}$ with phosphate buffer. Dehydration was performed at increasing ethanol concentrations $(50 \%, 60 \%, 70 \%, 80 \%, 90 \%$, and $100 \%)$ at 10 min intervals. Finally, acetone was added for $10 \mathrm{~min}$ intervals. The dried samples were gold-coated utilizing a model 108 auto sputter coater (Cressington Scientific Instruments, Watford, UK) and three-dimensional structure was observed by LV-SEM (JSM-6610LV,JEOL, Tokyo, Japan).

\section{Statistical analysis}

Data of all experiments were analyzed by one-way of ANOVA using IBM SPSS 23.0 statistical software (SPSS, Chicago, IL, USA). Each experiment was repeated three times. Significant differences were determined at $p$-value of $<0.05$ by Duncan's multiple range test.

\section{RESULTS AND DISCUSSION}

\section{Evaluation of chicken breast sausage with various levels of salt}

As shown in Table $3, \mathrm{pH}$ values were not different among the treatments $(p>0.05)$. Different salt concentrations didn't affect the $\mathrm{pH}$ of chicken breast sausages $(p>0.05)$. Lee and Chin [13] re-

Table 3. pH and color value of chicken sausages with various level of salt

\begin{tabular}{|c|c|c|c|c|c|}
\hline \multirow{2}{*}{ Variables } & \multicolumn{5}{|c|}{ Treatments } \\
\hline & TRT1 & TRT2 & TRT3 & TRT4 & TRT5 \\
\hline $\mathrm{pH}$ & $6.32 \pm 0.03^{\mathrm{a}}$ & $6.31 \pm 0.07^{a}$ & $6.29 \pm 0.08^{\mathrm{a}}$ & $6.27 \pm 0.10^{\mathrm{a}}$ & $6.22 \pm 0.10^{\mathrm{a}}$ \\
\hline CIE L* (lightness) & $82.4 \pm 0.34^{\mathrm{a}}$ & $80.5 \pm 0.48^{b}$ & $80.1 \pm 0.34^{\mathrm{bc}}$ & $79.6 \pm 0.30^{\text {cd }}$ & $79.2 \pm 0.45^{d}$ \\
\hline $\mathrm{CIE} \mathrm{a*} \mathrm{(redness)}$ & $5.91 \pm 0.46^{a}$ & $5.36 \pm 0.37^{\mathrm{ab}}$ & $5.03 \pm 0.22^{b}$ & $4.99 \pm 0.36^{b}$ & $4.74 \pm 0.35^{b}$ \\
\hline CIE b* (yellowness) & $5.58 \pm 0.50^{\mathrm{a}}$ & $5.11 \pm 0.36^{\mathrm{ab}}$ & $4.79 \pm 0.13^{b}$ & $4.78 \pm 0.14^{b}$ & $4.92 \pm 0.04^{b}$ \\
\hline
\end{tabular}

${ }^{\mathrm{a}-\mathrm{d}} \mathrm{Mean}$ with different superscripts in a same row are different $(p<0.05)$.

TRT1, Treatment 1 (0.3\% salt); TRT2, Treatment 2 ( $0.8 \%$ salt); TRT3, Treatment 3 (1.3\% salt); TRT4, Treatment 4 (1.8\% salt); TRT5, Treatment 5 (2.3\% salt). 
ported that low-fat pork sausages with different levels of salt $(0.75 \%, 1.0 \%, 1.25 \%$, and $1.5 \%)$ didn't differ in $\mathrm{pH}$. Also, restructured pork ham containing salt from $0.5 \%$ to $1.5 \%$ did not change $\mathrm{pH}$ [14]. Aaslyng, Vestergaard and Koch [15] found salt did not affect the $\mathrm{pH}$, regardless of the kind of meat products such as sausage, bacon, ham and salami. In terms of color values, lightness (CIE L*) decreased with increasing salt content $(p<0.05)$. TRT1 ( $0.3 \%$ salt) had the highest redness (CIE $\left.\mathrm{a}^{*}\right)$ and yellowness $\left(\mathrm{CIE} \mathrm{b}^{*}\right)$ values $(p<0.05)$. As the salt level increased, the color values tended to decrease. Trout [16] reported sodium chloride in cooked ground beef muscle caused an increase in the denatured myoglobin (\%) at the normal cooking temperature of meat and as sodium chloride level increased, denatured myoglobin (\%) also increased linearly [16]. Therefore, Trout [16] concluded that addition of salt reduced the pink color of cooked meat products. According to Jeong's study [17], the CIE $\mathrm{L}^{*}$ and $\mathrm{b}^{*}$ values with various $\mathrm{NaCl}$ levels showed similar trends to our results. He also reported that the addition of salt (except $\geq 2 \%$ ) might be able to increase CIE $\mathrm{a}^{*}$ of cooked chicken breast. However, redness of salt at $0.8 \%$ in chicken sausage didn't differ from $0.3 \%$.

As shown in Table 4, EM (\%) was increased with decreasing of salt levels and addition of salt at $1.3 \%$ (TRT3) was similar to the higher levels of salt (TRT4, 1.8\%; TRT 5, 2.3\% salt) $(p<0.05)$. In fact, TRT $5(2.3 \%$ salt $)$ was the lowest. The results of CL showed similar trends to the EM (Table 4). TRT 4 and 5 had the lowest amount of drip during cooking processing $(p<0.05)$. According to previous research, increased salt levels of chicken breast gels increased the water-holding capacity, and decreased CL [18]. Another study found the cooking yield of cooked ground chicken breasts tended to increase with increased $\mathrm{NaCl}$ level [17]. Lee and Chin [14] previously reported that CL increased in reduced-salt restructured ham. Salt caused the extraction of salt-soluble protein (myofibrillar protein) which is important in emulsifiers and stabilizers in meat products and help to bind meat proteins. In the higher salt level, chloride ions bind to the protein filaments. Therefore, negative charge of filaments increases and causes electrostatic repulsion among the myofibrillar proteins [3,19]. Thus, the adsorption of chloride ions with myosin caused swelling of myofibrils and increased water-holding capacity [3]. In a previous study, the addition of $1 \%$ salt reduced chicken muscle shrinkage greatly due to increased water-holding capacity, an effect that depended on phosphate [20].

Table 5 shows that all textural properties of chicken breast sausage except for springiness were

Table 4. Expressible moisture and cooking loss of chicken sausages with various levels of salt

\begin{tabular}{lccccc}
\hline \multirow{2}{*}{ Variables } & \multicolumn{5}{c}{ Treatments } \\
\cline { 2 - 6 } & TRT1 & TRT2 & TRT3 & TRT4 & TRT5 \\
\hline Expressible moisture (\%) & $30.6 \pm 1.64^{\mathrm{a}}$ & $23.1 \pm 0.80^{\mathrm{b}}$ & $21.8 \pm 1.67^{\mathrm{bc}}$ & $20.9 \pm 1.88^{\mathrm{bc}}$ & $20.3 \pm 0.37^{\mathrm{c}}$ \\
Cooking loss $(\mathrm{g})$ & $3.00 \pm 0.61^{\mathrm{a}}$ & $1.13 \pm 0.48^{\mathrm{b}}$ & $0.54 \pm 0.16^{\mathrm{bc}}$ & $0.33 \pm 0.08^{\mathrm{c}}$ & $0.27 \pm 0.01^{\mathrm{c}}$ \\
\hline
\end{tabular}

${ }^{a-c}$ Mean with different superscripts in a same row are different $(p<0.05)$.

TRT1, Treatment 1 (0.3\% salt); TRT2, Treatment 2 ( $0.8 \%$ salt); TRT3, Treatment 3 (1.3\% salt); TRT4, Treatment 4 (1.8\% salt); TRT5, Treatment 5 ( $2.3 \%$ salt).

Table 5. Textural profile analysis of chicken sausages with various levels of salt

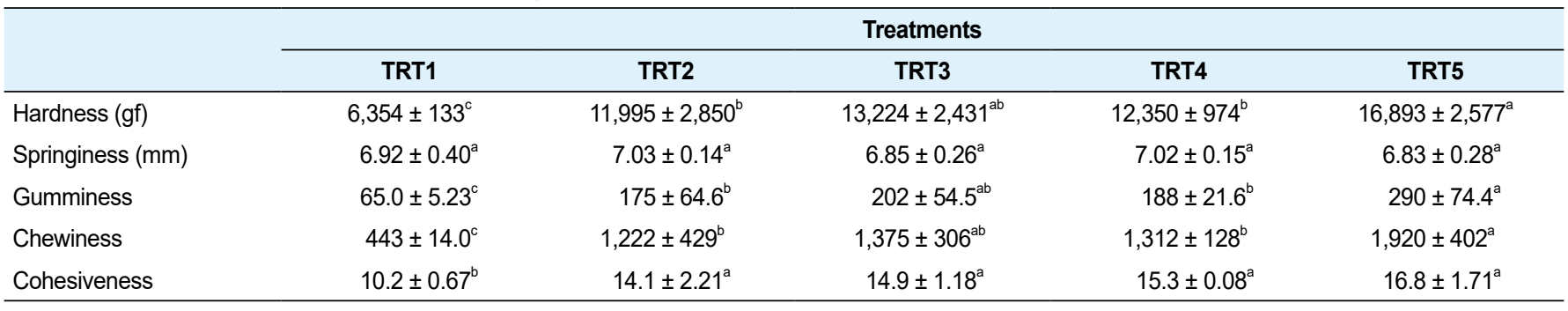

${ }^{\mathrm{a}-\mathrm{c} M e a n}$ with different superscripts in a same row are different $(p<0.05)$.

TRT1, Treatment 1 (0.3\% salt); TRT2, Treatment 2 ( $0.8 \%$ salt); TRT3, Treatment 3 (1.3\% salt); TRT4, Treatment 4 (1.8\% salt); TRT5, Treatment 5 (2.3\% salt). 
affected by various salt levels $(p<0.05)$. TRT 5 (2.3\% salt) showed the highest hardness score $(p<$ $0.05)$, and TRT $3(1.3 \%$ salt) was similar to TRT 5 on hardness, gumminess and chewiness $(p<0.05)$. In cohesiveness, TRT $1(0.3 \%$ salt $)$ showed the lowest result, but the others didn't differ. Tobin et al. [21] reported that salt level affected not only color, sensory and CL, but also texture of frankfurters. And lower salt levels caused increased CL, resulted in lower hardness, springiness, cohesiveness, chewiness and resilience in another study [21]. Similar trends were also observed in the results of $\mathrm{Li}$ et al. [18].

\section{Evaluation of chicken breast sausage with various levels of salt and sodium trip- olyphosphate}

As shown in Table 6, pH showed no differences among the formulations without STPP, but addition of $0.3 \%$ STPP (TRT 7, 9, 11) caused $\mathrm{pH}$ value to increase, regardless of salt addiiton. A previous study reported that STPP increased the $\mathrm{pH}$ of chicken patties, but sodium didn't affect $\mathrm{pH}$ if STPP was not incorporated [22]. However, in presence of STPP, sausages with $1.8 \%$ sodium (TRT 11) decreased $\mathrm{pH}$ slightly as compared to those without salt treatment (TRT 7). In other study, regardless of salt content, addition of $0.4 \%$ STPP did not change the $\mathrm{pH}$ in raw comminuted beef [23]. Thus, various salt/STPP combination could have interactive effects on $\mathrm{pH}$, depending on their contents.

In color values, lightness (CIE L*) was not different $(p>0.05)$, but redness (CIE a*) and yellowness $\left(\mathrm{CIE} \mathrm{b}^{*}\right)$ values tended to decrease with the addition of salt and STPP $(p<0.05)$. In a previous study, salt and phosphate affected the color of cooked pork meat batters [24]. According to the results of proximate analysis (Table 7), moisture content (\%) increased with increased levels of salt and STPP $(p<0.05)$, however, no differences in fat and protein contents $(\%)$ were observed $(p>0.05)$. The reason why moisture was different among treatments was partially due to the increased CL (Table 8). In previous study [25], NaCl/STPP marination resulted in quality improvement of moisture content. And, it also improved water holding capacity and CL [25]. The reduced CL might

Table 6. pH and color value of chicken sausages with various levels of salt and sodium tripolyphosphate (STPP)

\begin{tabular}{|c|c|c|c|c|c|c|}
\hline \multirow{2}{*}{ Variables } & \multicolumn{6}{|c|}{ Treatments } \\
\hline & TRT6 & TRT7 & TRT8 & TRT9 & TRT10 & TRT11 \\
\hline $\mathrm{pH}$ & $6.16 \pm 0.03^{c}$ & $6.32 \pm 0.03^{a}$ & $6.17 \pm 0.01^{c}$ & $6.28 \pm 0.03^{\mathrm{ab}}$ & $6.16 \pm 0.03^{c}$ & $6.26 \pm 0.04^{b}$ \\
\hline CIE L* (lightness) & $80.3 \pm 5.25^{\mathrm{a}}$ & $81.7 \pm 0.38^{a}$ & $81.5 \pm 0.53^{a}$ & $79.4 \pm 0.39^{\mathrm{a}}$ & $79.4 \pm 0.36^{\mathrm{a}}$ & $78.0 \pm 0.21^{a}$ \\
\hline CIE a* (redness) & $4.84 \pm 0.68^{a b}$ & $4.61 \pm 0.26^{\mathrm{ab}}$ & $5.10 \pm 0.54^{a}$ & $4.04 \pm 0.31^{\mathrm{bc}}$ & $4.76 \pm 0.42^{\mathrm{ab}}$ & $3.60 \pm 0.30^{c}$ \\
\hline CIE b* (yellowness) & $7.68 \pm 0.05^{\mathrm{ab}}$ & $8.09 \pm 0.12^{a}$ & $7.63 \pm 0.20^{\mathrm{ab}}$ & $7.18 \pm 0.56^{\mathrm{bc}}$ & $7.27 \pm 0.65^{\mathrm{bc}}$ & $6.62 \pm 0.40^{c}$ \\
\hline
\end{tabular}

${ }^{\mathrm{a}-\mathrm{c}}$ Mean with different superscripts in a same row are different $(p<0.05)$.

TRT6, Treatment 6 ( $0 \%$ salt, 0\% STPP); TRT7, Treatment 7 (0\% salt, 0.3\% STPP); TRT8, Treatment 8 ( $0.8 \%$ salt, $0 \%$ STPP); TRT9, Treatment 9 (0.8\% salt, 0.3\% STPP); TRT10, Treatment 10 (1.8\% salt, $0 \%$ STPP); TRT 11 , Treatment 11 (1.8\% salt, $0.3 \%$ STPP).

Table 7. Proximate analysis of chicken sausages with various levels of salt and sodium tripolyphosphate (STPP)

\begin{tabular}{|c|c|c|c|c|c|c|}
\hline \multirow{2}{*}{ Variables } & \multicolumn{6}{|c|}{ Treatments } \\
\hline & TRT6 & TRT7 & TRT8 & TRT9 & TRT10 & TRT11 \\
\hline Moisture (\%) & $78.3 \pm 0.38^{c}$ & $79.5 \pm 0.21^{b}$ & $79.7 \pm 0.06^{b}$ & $80.6 \pm 0.20^{a}$ & $79.7 \pm 0.06^{b}$ & $80.3 \pm 0.41^{a}$ \\
\hline Fat (\%) & $0.65 \pm 0.02^{a}$ & $0.58 \pm 0.02^{a}$ & $0.63 \pm 0.05^{a}$ & $0.59 \pm 0.04^{a}$ & $0.67 \pm 0.04^{a}$ & $0.57 \pm 0.08^{a}$ \\
\hline Protein (\%) & $18.6 \pm 0.99^{a}$ & $18.2 \pm 1.19^{a}$ & $17.6 \pm 0.58^{a}$ & $17.1 \pm 0.84^{a}$ & $17.2 \pm 0.33^{\mathrm{a}}$ & $17.0 \pm 0.74^{a}$ \\
\hline
\end{tabular}

${ }^{a-c}$ Mean with different superscripts in a same row are different $(p<0.05)$.

TRT6, Treatment 6 ( $0 \%$ salt, $0 \%$ STPP); TRT7, Treatment 7 ( $0 \%$ salt, $0.3 \%$ STPP); TRT8, Treatment $8(0.8 \%$ salt, $0 \%$ STPP); TRT9, Treatment 9 (0.8\% salt, $0.3 \%$ STPP); TRT10, Treatment 10 (1.8\% salt, $0 \%$ STPP); TRT 11 , Treatment 11 (1.8\% salt, $0.3 \%$ STPP). 
Table 8. Expressible moisture and cooking loss of chicken sausages with various levels of salt and sodium tripolyphosphate (STPP)

\begin{tabular}{lcccccc}
\hline \multirow{2}{*}{ Variables } & \multicolumn{5}{c}{ Treatments } \\
\cline { 2 - 7 } & TRT6 & TRT7 & TRT8 & TRT9 & TRT10 & TRT11 \\
\hline Expressible moisture (\%) & $41.3 \pm 1.75^{\mathrm{a}}$ & $41.7 \pm 1.83^{\mathrm{a}}$ & $40.6 \pm 0.77^{\mathrm{a}}$ & $30.8 \pm 1.93^{\mathrm{b}}$ & $33.9 \pm 3.45^{\mathrm{b}}$ & $22.4 \pm 1.17^{\mathrm{c}}$ \\
Cooking loss (g) & $7.30 \pm 0.75^{\mathrm{a}}$ & $5.58 \pm 0.66^{\mathrm{b}}$ & $4.04 \pm 0.64^{\mathrm{c}}$ & $2.39 \pm 0.49^{\mathrm{d}}$ & $2.81 \pm 0.29^{\mathrm{d}}$ & $0.34 \pm 0.11^{\mathrm{e}}$ \\
\hline
\end{tabular}

${ }^{\mathrm{a}-\mathrm{e}}$ Mean with different superscripts in a same row are different $(p<0.05)$.

TRT6, Treatment 6 ( $0 \%$ salt, $0 \%$ STPP); TRT7, Treatment 7 ( $0 \%$ salt, $0.3 \%$ STPP); TRT8, Treatment 8 ( $0.8 \%$ salt, $0 \%$ STPP); TRT9, Treatment $9(0.8 \%$ salt, $0.3 \%$ STPP); TRT10, Treatment 10 (1.8\% salt, $0 \%$ STPP); TRT11, Treatment 11 (1.8\% salt, $0.3 \%$ STPP).

decrease the moisture content of the sausage, indicating that salt and STPP increased the moisture content of the final meat product. As salt level increased, CL and EM tended to decrease, and the combination of the salt and STPP was even further lower than salt addition alone (Table 8) $p<$ $0.05)$. According to the previous study, low salt content $(<1.0 \%$ and $1.5 \%)$ of turkey frankfurters had lower smokehouse yield, as compared to those with high salt (> 2.0\%) without STPP [26]. However, regardless of salt levels, addition of phosphate reduced the difference in yield [26]. Villamonte et al. [24] reported that the addition of salt increased the water-holding capacity and decreased CL of the cooked pork meat batters at $3 \%$ salt, and polyphosphate reduced the CL without affecting water-holding capacity. Our results showed that salt and STPP in combination affected EM and CL, even though salt level was low. Furthermore, the addition of phosphate resulted in reduced CL and increased water-binding properties [27].

In TPA (Table 9), hardness and springiness tended to increase with increasing salt and STPP levels $(p<0.05)$. These results of gumminess, chewiness and cohesiveness showed that $1.8 \%$ salt and $0.3 \%$ STPP combination had the best properties $(p<0.05)$. In other study of low-fat $(1.2 \%)$ and single-step high-pressure processed chicken breast sausages, addition of STPP caused a decrease in hardness and chewiness [28]. However, our study turned out to be contrary to these results. Sausage containing $0.3 \%$ STPP didn't decrease the textual properties. Li et al. [18] reported that increasing salt level from $1 \%$ to $2 \%$ increased TPA and gel strength of chicken meat gels. In addition, $1.5 \%$ salt in combination with $0.3 \%$ STPP had higher TPA values than those with $1.5 \%$ salt alone [29].

Fig. 1 shows the three dimensional microstructure of sausage with various salt and STPP combinations. Regardless of the addition of STPP, the increased levels of salt made the surface flatter and reduced surface pores. Sausages containing 1.8\% salt and 0.3\% STPP had the flattest surface and the most compact structure. In results of Li et al. [18], there were difference of microstructure according to salt level as it increased from $1 \%$ to $2 \%$. One $\%$ salt meat gel had a plate-like and disorganized structure with a lot of aggregates and $2 \%$ salt formed structure with small pore among the protein strands. However, our results showed that the addition of STPP affected structure to

Table 9. Textural p rofile analysis of chicken sausages with various level of salt and sodium tripolyphosphate (STPP)

\begin{tabular}{|c|c|c|c|c|c|c|}
\hline \multirow{2}{*}{ Variables } & \multicolumn{6}{|c|}{ Treatments } \\
\hline & TRT6 & TRT7 & TRT8 & TRT9 & TRT10 & TRT11 \\
\hline Hardness (gf) & $2,765 \pm 880^{\mathrm{bc}}$ & $1,842 \pm 369^{c}$ & $2,642 \pm 721^{b c}$ & $3,792 \pm 493^{b}$ & $3,118 \pm 467^{b c}$ & $6,973 \pm 1,812^{\mathrm{a}}$ \\
\hline Springiness (mm) & $4.55 \pm 0.46^{c}$ & $5.87 \pm 0.80^{\mathrm{b}}$ & $5.75 \pm 0.74^{b}$ & $7.53 \pm 0.15^{a}$ & $7.56 \pm 0.28^{a}$ & $7.40 \pm 0.11^{\mathrm{a}}$ \\
\hline Gumminess & $30.1 \pm 15.8^{b}$ & $14.9 \pm 4.55^{b}$ & $25.4 \pm 12.9^{b}$ & $32.2 \pm 5.89^{b}$ & $23.4 \pm 5.25^{b}$ & $81.6 \pm 33.2^{\mathrm{a}}$ \\
\hline Chewiness & $133 \pm 56.7^{b}$ & $89.3 \pm 36.8^{b}$ & $139 \pm 57.9^{b}$ & $240 \pm 43.6^{b}$ & $187 \pm 24.6^{b}$ & $614 \pm 246^{a}$ \\
\hline Cohesiveness & $8.60 \pm 1.00^{b}$ & $7.90 \pm 0.89^{b}$ & $9.03 \pm 1.90^{b}$ & $8.42 \pm 0.64^{b}$ & $7.47 \pm 0.68^{\mathrm{b}}$ & $11.7 \pm 1.26^{\mathrm{a}}$ \\
\hline
\end{tabular}

${ }^{a-c}$ Mean with different superscripts in a same row are different $(p<0.05)$.

TRT6, Treatment 6 ( $0 \%$ salt, $0 \%$ STPP); TRT7, Treatment 7 ( $0 \%$ salt, $0.3 \%$ STPP); TRT8, Treatment 8 ( $0.8 \%$ salt, $0 \%$ STPP); TRT9, Treatment $9(0.8 \%$ salt, $0.3 \%$ STPP); TRT10, Treatment 10 (1.8\% salt, $0 \%$ STPP); TRT11, Treatment 11 (1.8\% salt, $0.3 \%$ STPP). 

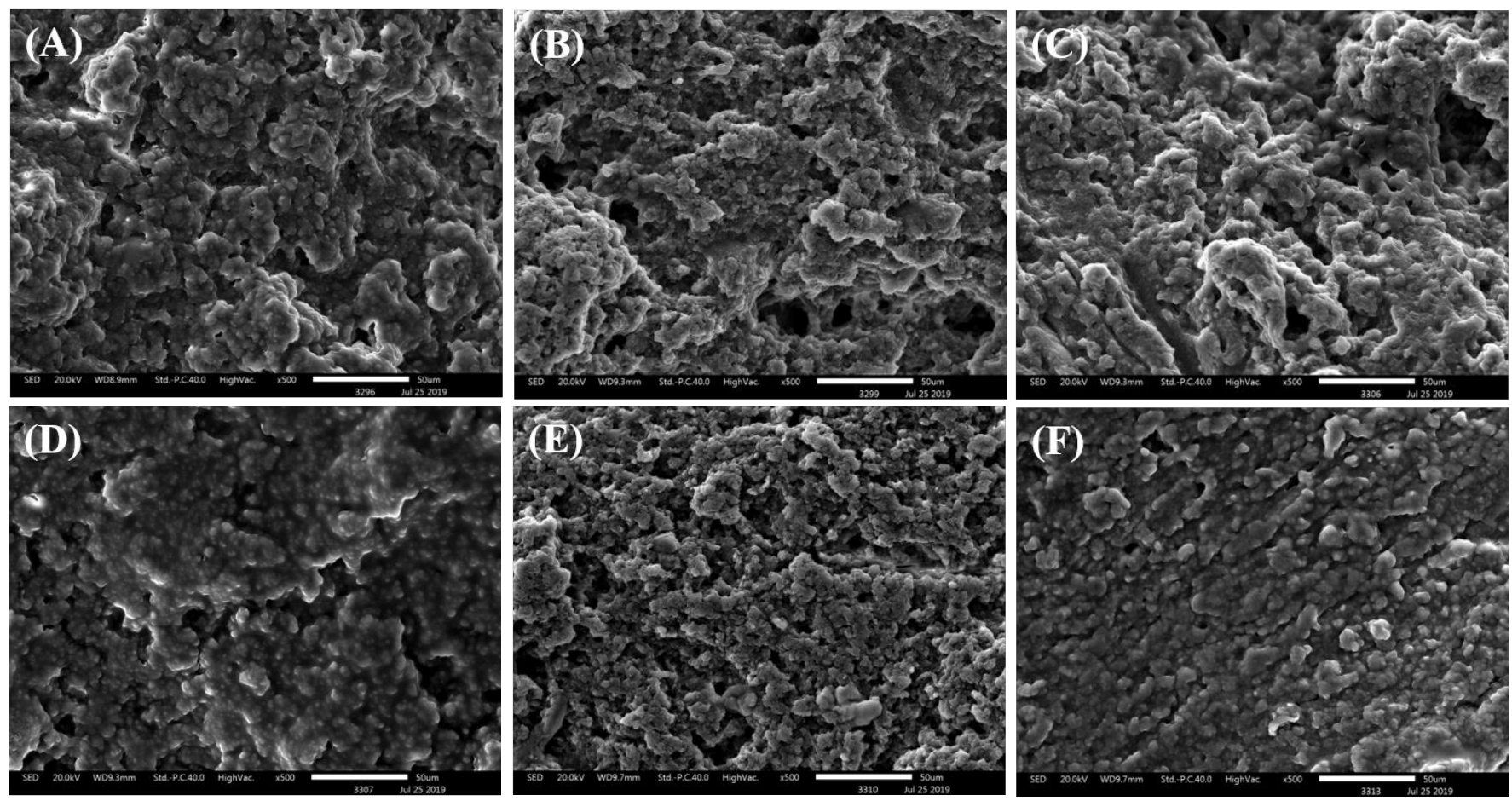

Fig. 1. Scanning microscopy $(\times 500)$ of chicken breast sausages with various levels of salt and sodium tripolyphosphate (STPP). (A) TRT6, Treatment 6 (0\% salt, 0\% STPP); (B) TRT7, Treatment 7 (0\% salt, 0.3\% STPP); (C) TRT8, Treatment 8 ( $0.8 \%$ salt, $0 \%$ STPP); (D) TRT9, Treatment 9 (0.8\% salt, $0.3 \%$ STPP); (E) TRT10, Treatment 10 (1.8\% salt, 0\% STPP); (F) TRT11, Treatment 11 (1.8\% salt, $0.3 \%$ STPP).

make it plate-like and small pore structures appeared above $0.8 \%$ salt. Another study reported that muscle junctions at higher salt and phosphate levels showed a high level of junction alignment and binding properties [30]. During the massaging process, the absence of salt or polyphosphate caused muscle fibers to break, and fragments were observed [31].

In conclusion, addition of salt and phosphate affects the functionality, textural and physicochemical properties of chicken breast sausages. Although salt or STPP affects the quality of meat products, they are considered to have mutually dependent effects, because these effects based on the difference of concentration and combination of two ingredients. Therefore, meat products should have minimum level of additives during processing, and attempts should be made to reduce salt content (\%) with the addition of STPP, resulting in similar characteristics to those with regular-salt meat products. Therefore, STPP addition along with salt will be replaced with partial amounts of salt contents in the manufacture of low-salt meat products.

\section{REFERENCES}

1. Powell MJ, Sebranek JG, Prusa KJ, Tarté R. Evaluation of citrus fiber as a natural replacer of sodium phosphate in alternatively-cured all-pork Bologna sausage. Meat Sci. 2019;157:107883.

2. Ruusunen M, Puolanne E. Reducing sodium intake from meat products. Meat Sci. 2005;70:531-41.

3. Desmond E. Reducing salt: a challenge for the meat industry. Meat Sci. 2006;74:188-96.

4. Wang YR, Zhang B, Fan JL, Yang Q, Chen HQ. Effects of sodium tripolyphosphate modification on the structural, functional, and rheological properties of rice gluten. Food Chem. 2019;281:18-27. 
5. Trout GR, Schmidt GR. Effect of chain length and concentration on the degree of dissociation of phosphates used in food products. J Agric Food Chem. 1986;34:41-5.

6. Szerman N, Ferrari R, Sancho AM, Vaudagna S. Response surface methodology study on the effects of sodium chloride and sodium tripolyphosphate concentrations, pressure level and holding time on beef patties properties. LWT. 2019;109:93-100.

7. Muguruma M, Tsuruoka K, Katayama K, Erwanto Y, Kawahara S, Yamauchi K, et al. Soybean and milk proteins modified by transglutaminase improves chicken sausage texture even at reduced levels of phosphate. Meat Sci. 2003;63:191-7.

8. Schwartz WC, Mandigo RW. Effect of salt, sodium tripolyphosphate and storage on restructured pork. J Food Sci. 1976;41:1266-9.

9. Kondaiah N, Anjaneyulu ASR, Rao VK, Sharma N, Joshi HB. Effect of salt and phosphate on the quality of buffalo and goat meats. Meat Sci. 1985;15:183-92.

10. Jauregui CA, Regenstein JM, Baker RC. A simple centrifugal method for measuring expressible moisture, a water-binding property of muscle foods.J Food Sci. 1981;46:1271.

11. Bourne MC. Texture profile analysis. Food Technol. 1978;32:62-6.

12. AOAC [Association of Official Analytical Chemists] International. Official methods of analysis of AOAC International. 17th ed. Gaithersburg, MD: AOAC International; 2000.

13. Lee HC, Chin KB. Physicochemical, textural, and sensory properties of low-fat/reduced-salt sausages as affected by salt levels and different type and level of milk proteins. Food Sci Biotechnol. 2009;18:36-42.

14. Lee $\mathrm{HC}$, Chin KB. Evaluation of various salt levels and different dairy proteins in combination with microbial transglutaminase on the quality characteristics of restructured pork ham. Int J Food Sci Technol. 2011;46:1522-8.

15. Aaslyng MD, Vestergaard C, Koch AG. The effect of salt reduction on sensory quality and microbial growth in hotdog sausages, bacon, ham and salami. Meat Sci. 2014;96:47-55.

16. Trout GR. Variation in myoglobin denaturation and color of cooked beef, pork, and turkey meat as influenced by $\mathrm{pH}$, sodium chloride, sodium tripolyphosphate, and cooking temperature.J Food Sci. 1989;54:536-40.

17. Jeong JY. Effects of short-term presalting and salt level on the development of pink color in cooked chicken breasts. Korean J Food Sci Anim Resour. 2017;37:98-104.

18. Li K, Kang ZL, Zou YF, Xu XL, Zhou GH. Effect of ultrasound treatment on functional properties of reduced-salt chicken breast meat batter.J Food Sci Technol. 2015;52:2622-33.

19. Offer $\mathrm{G}$, Trinick J. On the mechanism of water holding in meat: the swelling and shrinking of myofibrils. Meat Sci. 1983;8:245-81.

20. Shults GW, Wierbicki E. Effects of sodium chloride and condensed phosphates on the waterholding capacity, pH and swelling of chicken muscle. J Food Sci. 1973;38:991-4.

21. Tobin BD, O'Sullivan MG, Hamill RM, Kerry JP. Effect of varying salt and fat levels on the sensory and physiochemical quality of frankfurters. Meat Sci. 2012;92:659-66.

22. Young LL, Lyon CE, Searcy GK, Wilson RL. Influence of sodium tripolyphosphate and sodium chloride on moisture-retention and textural characteristics of chicken breast meat patties. J Food Sci. 1987;52:571-4.

23. Clarke AD, Means WJ, Schmidt GR. Effects of storage time, sodium chloride and sodium tripolyphosphate on yield and microstructure of comminuted beef.J Food Sci. 1987;52:854-6.

24. Villamonte G, Simonin H, Duranton F, Chéret R, de Lamballerie M. Functionality of pork meat proteins: impact of sodium chloride and phosphates under high-pressure processing. Innovative Food Sci Emerging Technol. 2013;18:15-23.

25. Detienne NA, Wicker L. Sodium chloride and tripolyphosphate effects on physical and quality 
characteristics of injected pork loins. J Food Sci. 1999;64:1042-7.

26. Barbut S, Maurer AJ, Lindsay RC. Effects of reduced sodium chloride and added phosphates on physical and sensory properties of turkey frankfurters.J Food Sci. 1988;53:62-6.

27. Siegel DG, Theno DM, Schmidt GR, Norton HW. Meat massaging: the effects of salt, phosphate and massaging on cooking loss, binding strength and exudate composition in sectioned and formed ham.J Food Sci. 1978;43:331-3.

28. Xue S, Zou Y, Chen X, Yang H, Xing T, Xu X, et al. Effects of sodium tripolyphosphate on functional properties of low-salt single-step high-pressure processed chicken breast sausage. Int J Food Sci Technol. 2016;51:2106-13.

29. Fernández-Martín F, Cofrades S, Carballo J, Jiménez-Colmenero F. Salt and phosphate effects on the gelling process of pressure/heat treated pork batters. Meat Sci. 2002;61:15-23.

30. Theno DM, Siegel DG, Schmidt GR. Meat massaging: effects of salt and phosphate on the microstructure of binding junctions in sectioned and formed hams. J Food Sci. 1978;43:493-8.

31. Theno DM, Siegel DG, Schmidt GR. Meat massaging: effects of salt and phosphate on the microstructural composition of the muscle exudate.J Food Sci. 1978;43:483-7. 